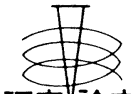

研究論交

\title{
ばね-はりモデルによるねじ締結体の応力解析* 一締付線図への応用—
}

\author{
田 中 稔** 北郷 薰***
}

The Stress Analysis of Bolted Joint with Model using Spring-Beam Elements

-Application to the Force-Deformation Diagram of Bolted Joint-

\section{Minoru Tanaka and Kaoru Hongo}

The force-deformation diagram has been used to understand the mechanical behavior of a bolted joint. There are, however, no report on the force-deformation diagram of multi-bolted joint. In this paper the author's finite element method using spring-beam elements is applied to construct the force-deformation diagram of multi-bolted joint as well as single-bolted joint. The force-deformation diagram of multi-bolted joint is expressed as the relationship between the sum of axial tension in each bolt and the expansion of a bolt. Using this diagram, not noly the relationship between axial tension and expansion of each bolt but also the relationship between compression and reaction in the contact surface produced by the lever action can be obtained for any applied load.

Key words : fixing element, force-deformation diagram, spring-beam element, multi-bolted joint, finite element method

\section{1. 緒}

ねじ締結体において，ボルトで被締結体を締め付け るとボルト及び被締結体に弾性変形が生じ，この弾性 変形の復元力によって締付け力が保持される.この締 結体に外力が作用すると, 弾性変形の様子が变化する. このよらな締結状態の力学を理解しやすくするために 締付線図がよく用いられている。一般に用いられてい る締付線図は外力の着力点がボルト軸線上のボルト・ ナット座面直下にある場合について表したものが多 い. しかし, 実際の場合は外力の作用点がボルト軸線 から離れ，かつ被締結体の表面から外れた所にあるの が普通であるが，このよらな状態の締付線図を表して いる例は少ない。これは，被締結体に外力が作用した ときの着力点の違いによるばね定数の変化の決定や接 合面の分離を考慮した場合の被締結体のばね定数の決 定など理論的に計算することが難しい問題があるため ‘゙ある，筆者らは，外力を受けるねじ締結体のボルト の応力挙動を簡単に求めることを目的に，ばねーはり モデルによる解析法を提案 ${ }^{1) 3)}$ している. この解析法

* 原稿受付 昭和 62 年 5 月 6 日. 昭和 61 年度精密工学会 春季大会学術講演会（昭和 61 年 3 月 30 日）にて発表

** 正会 員 室蘭工業大学 (室蘭市水元町 27-1)

*** 正 会 員 工学院大学 (東京都新宿区西新宿 1-24-2)
によるとボルトの追加軸力や接合面の圧縮力の減少分 を簡単に求めることができる. そこで，本研究では， まず，このばねーはりモデルによる解析法を利用して 単一ボルト締結体の締付線図を作図する方法を示す. 更に, 従来, 発表されていない複数ボルト締結体の締 付線図を作図する方法を提案する.

\section{2. ねじ締結体のモテル化と解析方法}

ねじ締結体に外力が作用するとき，被締結体におけ る外力の作用平面の位置によって内力係数が変化する ことが知られている4)5). これは, 外力の作用平面の位 㯰によって被締結体のばね定数が変化するためと考党 られる．そこで，図 1 (a) に示すよ5に $n H(n<1)$ の 位置に外力の作用平面があるとし, 前報 ${ }^{1)}$ (3) と同様に 被締結体の圧縮領域を外力の作用平面で座面側及び接 合面側に分離し, 各々を円筒に置き換えると, 各円筒 の直径は次式で表される.

$$
\left.\begin{array}{l}
D_{\mathrm{c}}=2 n H \tan \alpha+d_{s} \\
D_{\mathrm{t}}=2 H \tan \alpha+d_{s}
\end{array}\right\}
$$

座面側円筒を $m$ 個のばね要素にモデル化するとそ のばね定数は次式で表される.

$$
\left.\begin{array}{l}
k_{\mathrm{cl}}=k_{\mathrm{c}} / m \\
k_{\mathrm{c}}=A_{\mathrm{c}} E /(n H) \\
A_{\mathrm{c}}=\pi\left(D_{\mathrm{c}}{ }^{2}-d_{0}{ }^{2}\right) / 4
\end{array}\right\}
$$


(a)

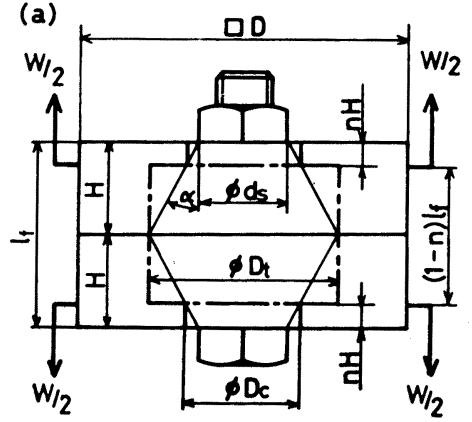

(b)

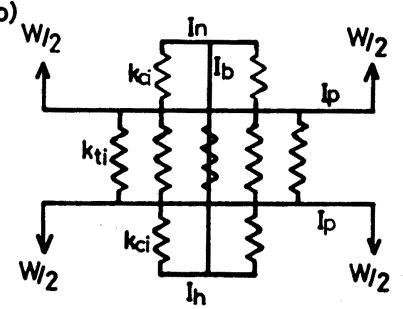

Fig. 1 Bolted joint and spring-beam model

また，接合面側円筒を $M$ 個のばね要素にモデル化 するとそのばね定数は次式で表される.

$$
\left.\begin{array}{l}
k_{\mathrm{t}}=A_{\mathrm{t}} k_{\mathrm{t}} / A \\
k_{\mathrm{t}}=A E /\{2(1-n) H\} \\
A=\pi\left(D_{\mathrm{t}}{ }^{2}-d_{0}^{2}\right) / 4
\end{array}\right\}
$$

ここで, $E$ は縦弾性係数, $d_{0}$ はボルト穴の直径, $A_{\mathrm{tl}}$ は $A$ を $M$ 分割した時の分割部 ${ }^{1}$ の面積である.

図1 (b) は（a）のねじ締結体について，ボルトと被 締結体全体をはり要素, 被締結体の圧縮領域をばね要 素として組み立てたばねーはりモデルを示す．解析は （b）のモデルをばねとはりを要素とする有限要素法に より行う、ばね要素およびはり要素は, 各々骨組構造 に使われている平面トラス要素および平面ラーメン要 素に対応している.

計算過程では, 外力が増加すると接合面側のばね要 素は, 初期締付け力による圧縮力が開放される. 圧縮 力が完全に開放されたばね要素は構成要素から分離す る.さらに，片持ちはり形のねじ締結体の場合には， てこ作用により接合面に分布反力が生ずる. この分布 反力は, 外力の増加により材端側に移動する.この状 態を表すために，ボルト中心より材端側の被締結体に 相当するはり要素に初期締付け力により生じた变位を 与えることにより拘束し，この節点反力を接合面に生 ずる反力に対応させる，また，同時に 2 節点まで拘束 することにより分布反力に対応させている．支点とな る拘束節点の反力が負になる場合は，支点が移動する と考劣て拘束条件を解き，自由節点とし，次に材端側 の節点を拘束する. 支点となる拘束節点は材端に相当

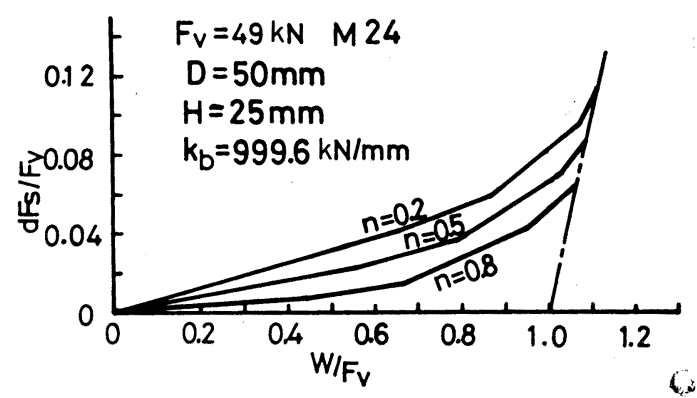

Fig. 2 The relationship between load and axial tension

する節点まで移動し，最終的には材端のみが支点とな る.

\section{3、単一ボルト締結体の締付線図}

ボルトのばね定数は比較的簡単に計算できるので,ば ねーはりモデルによる解析結果から山本の式5)を用い てボルトの伸びを求める.

\section{1 対称な外力を受けるねじ締結体}

図 2 は文献 4）を参考に計算した，外力の作用平面の 位置をパラメータとしたボルトの軸力と外力の関係を 示す. 図は座標軸を無次元化して表している，また， 図中の一点鎖線は接合面が完全に分離し外力と軸力の 増加が等しくなる点を示す. 外力の作用平面の位置が 座面側にある場合の軸力の増加は大きいが，接合面が 完全に分離するまでの外力も大きくなっていることが わかる. 解析結果は折れ線として表されている。 これ は, 計算過程において接合面側ばね要素の圧縮力が零 になったものを構成要素から分離するようにしている が，ばね要素が分離するまでは外力と軸力が比例関係 にあるため, この区間は直線となる。ばね要素が構成 要素から分離すると, 構造が変化するため直線の勾配 が変わる. 従って, 解析結果は, ばね要素が分離する 点から勾配が変わる折れ線として表される. しかし， 実際の場合は曲線になると考兄られる. 図 3 に $n=0.5$ の場合の締付線図を示す．OA はボルトの軸力と伸び の関係を表し, BF は外力がボルト・ナット座面直下に ある場合, $\mathrm{BCDE}$ は外力の作用平面が $n=0.5$ の場合 の被締結体の圧縮力と縮みの関係を表す，外力が表面 に作用する場合の王縮力之縮みの関係は直線となる が，外力が表面から離れた面に作用する時にはこの関 係が曲線になると考えられる。ここで， BC 愔接合面 が全面的に接合している区間で，CDE は両端で接合 面が分離している区間である．E拉よび Fで接合面は 完全に分離する．接合面が完全に分離した後では外力 とボルト軸力が等しくなる. 


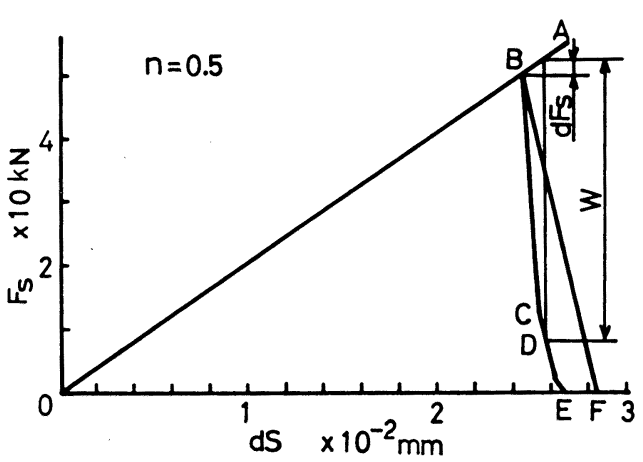

Fig. 3 Force-deformation diagram of single bolted joint

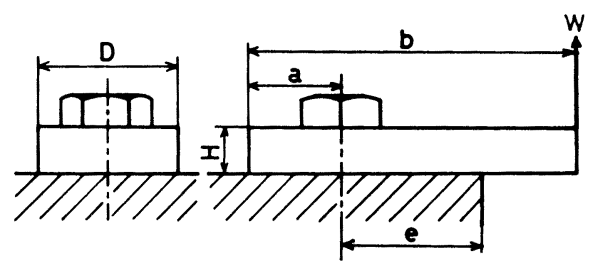

Fig. 4 Bolted joint subjected to an eccentric load

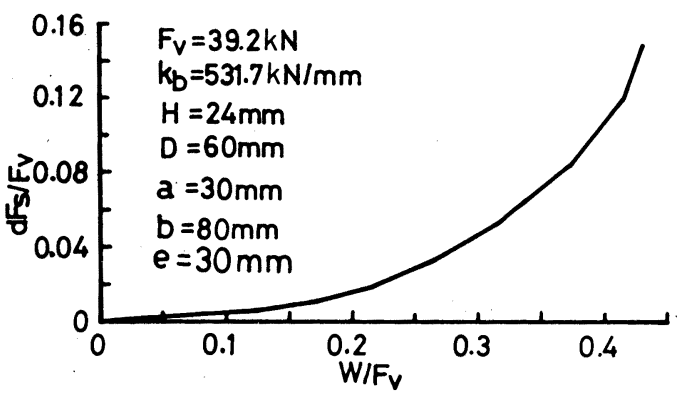

Fig. 5 The relationship between load and axial tension

\section{2 偏心外力を受けるねじ締結体}

図 4 は偏心外力を受けるねじ締結体を示す。この場 合, 外力が増加すると接合面は分離するが，てこ作用 により接合面に反力が発生し，この反力の位置が外力 の增加とともに材端に移動する．接合面が完全に分離 しても，最終的にはてこ作用により材端が支点となる ため，外力と軸次の増加が等しくなることはない．図 5 は $n=0.5$ として解析した外力と軸力の関係を示す. ここで, ボルトは M 12, 軸部長さ $18 \mathrm{~mm}$ の植込みボ ルトして計算し, 座標軸は無次元化して表している.

図 6 はこの場合の締付線図である.OA は図 3 と同様 にボルト軸力と伸びの関係を示し， B B B'は初期締付 状態を表している。また， $\mathrm{BCDE}$ および $\mathrm{B}^{\prime} \mathrm{C}^{\prime} \mathrm{E}^{\prime}$ は被 締結体の圧縮力と縮みの関係を示す，OF は接合面が 材端のみで接触している時のボルトの伸びと反力の関

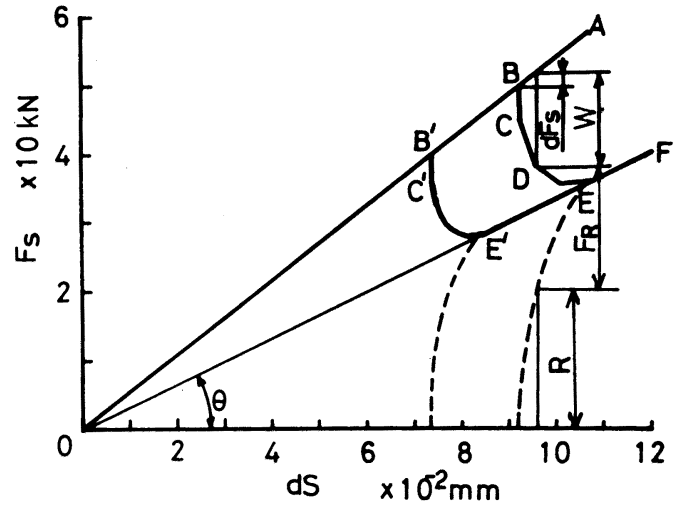

Fig. 6 Force-deformation diagram of bolted joint subjected to an eccentric load

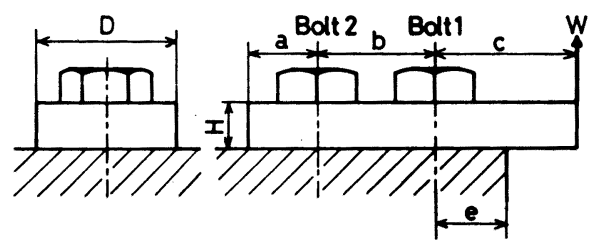

Fig. 7 Multi-bolted joint

係を示す，更に，図中の破線は接合面の反力を表して いる．Eおよび $\mathrm{E}^{\prime}$ 点は接合面が材端まで分離した点 で，これ以後は材端が支点となる. OF と横軸のなす 角 $\theta$ は次式で表される.

$$
\theta=\tan ^{-1} \frac{(b-a) k_{\mathrm{b}}}{b}
$$

ここで, $k_{\mathrm{b}}$ はボルトのばね定数である.

この図より，外力 $W$ が作用した時，ボルトの軸力 増加分 $\mathrm{d} F_{\mathrm{S}}$, 残留圧縮力 $F_{\mathrm{R}}$, てこ作用による反力 $R$ が 求められる.

\section{4. 複数ボルト締結体の締付線図}

図 7 に直列に並ぶ複数ボルト締結体を示す。これは 図 4 の偏心外力を受けるねじ締結体のボルトを 2 本に したもので, $n=0.5$ として解析している. 図 8 は初期 締付け力が各々等しい場合の外力と軸力の関係を示 す.ここで，ボルトは M 12 , 軸部長さ $18 \mathrm{~mm}$ の植込 みボルトとして計算している。この場合ボルト軸力は 着力点に近いボルト 1 の増加が大きくボルト 2 の増加 は非常に少ない。すなわち，外力の増加に対するボル 卜軸力の増加は各々のボルトで異なっている. 従って, 複数ボルトでは各々のボルトについて締付線図が作図 されることになる．しかしこの場合，外力が作用する と接合面には初期締付け力による圧縮力のほかにてこ 作用による反力が発生する。この反力を各々のボルト 


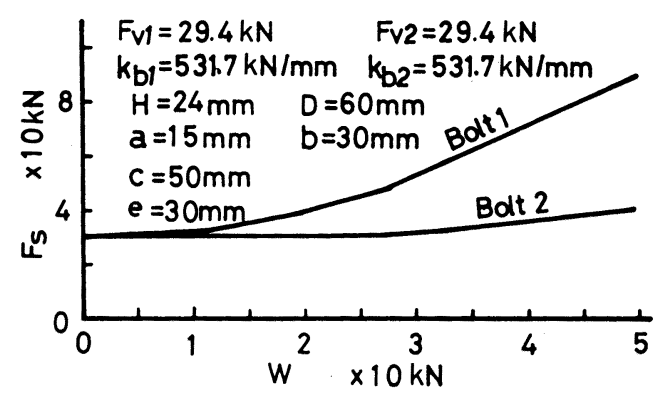

Fig. 8 The relationship between load and axial tension

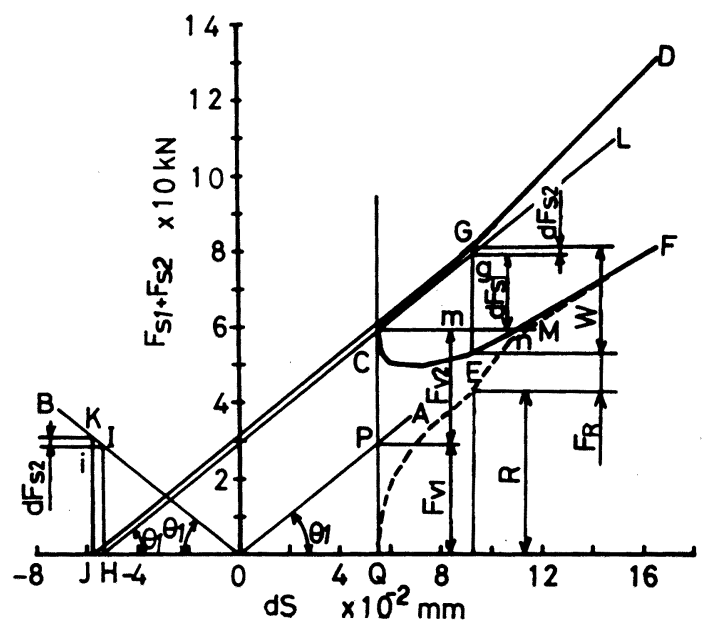

Fig. 9 Force-deformation diagram of multi-bolted joint

に分配することは難しい、ばねーはりモデルによる解 析法では各々のボルト軸力および接合面の圧縮力が簡 単に得られる. そこで, 本研究では各ボルト軸力の和 とボルトの伸びの関係として締付線図を表し, この線 困から各々のボルトの状態を推定する方法を提案す る.

\section{1 ボルトのばね定数が各々等しい場合}

図 9 は図 8 の関係を締付線図で表したものである. 横軸はボルトの伸びで縦軸はボルト軸力である. CGD はボルト 1,2 の軸力の和に対するボルト 1 の伸びの関 係を示し, CEF は接合面に打ける圧縮力と反力の和に 対するボルト 1 の伸びの関係を示している. また，図 中の破線は接合面の反力を表す. 外力 $W$ が作用した 時の残留圧縮力は $F_{\mathrm{R}}$ ，てこ作用による反力は $R$ とし て求められる.

CGD およびCEF から任意の外力に対するボルト 1 および 2 の状態を推定する方法を示す. 原点 $\mathrm{O} か ら$ ボルト 1 抢よびボルト 2 の軸力と伸びの関係を示す $\mathrm{OA}, \mathrm{OB}$ を引くこの場合はボルトのばね定数 $k_{\mathrm{b} 1}, k_{\mathrm{b} 2}$

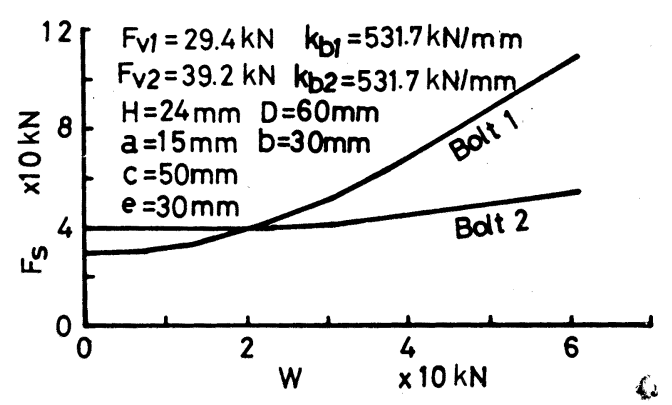

Fig. 10 The relationship between load and axial tension

が各々等しいので $\mathrm{OA}, \mathrm{OB}$ と横軸とのなす角は等し く,ボルトのばね定数を $k_{\mathrm{b} 1}$ とすると, $\theta_{1}=\tan ^{-1} k_{\mathrm{b} 1}$ と なる.ここではボルト 2 の伸びを符号を変えて表すこ とにする. C 点はボルト 1 が初期締付け力により伸び た位置で，軸力はボルト 1,2 の初期締付け力の和であ るから，C点から横軸に垂線を下ろし OA および横軸 との交点を $\mathrm{P}, \mathrm{Q}$ とすると, $\mathrm{PQ}, \mathrm{CP}$ は各々ボルト 1 お よび 2 の初期締付け力になっている. また，C点から $\mathrm{OA}$ に平行に $\mathrm{CH}$.を引き, $\mathrm{H}$ 点で横軸に垂線を立て, $\mathrm{OB}$ との交点をI とすると $\mathrm{HI}$ 抢よび $\mathrm{OH}$ はボルト 2 の初期締付け力および伸びを表す， CD 上の任意の点 $\mathrm{G}$ で各ボルトの状態を知るには, $\mathrm{C}$ 点から横軸に平行 に $\mathrm{CM}$ を引き， $\mathrm{OA}$ に平行に $\mathrm{CL}$ を引．更に $\mathrm{G}$ 点か ら横軸に垂線を下ろし CL, CM, CF との交点を各々、 $\mathrm{g}, \mathrm{m}, \mathrm{E}$ とする. $\mathrm{GE}, \mathrm{Gg}, \mathrm{gm}$ は各々外力, ボルト 2 打 よびボルト 1 の追加軸力を表す。また $\mathrm{Cm}$ はボルト 1 の追加伸びを表す。ボルト 2 の伸びは $\mathrm{G}$ から OA に平 行な $\mathrm{GJ}$ を引く横軸上の $\mathrm{HJ}$ として追加伸びが求め られる. また $\mathrm{J}$ 点で横軸に垂線を立て $\mathrm{OB}$ との交点を $\mathrm{K}, \mathrm{I}$ 点から横軸に平行線を引き $\mathrm{JK}$ との交点を $\mathrm{i}$ とす ると Ki はボルト 2 の追加軸力を表す. CF と CM の 交点を $\mathrm{n}$ とする, ボルト 1 の追加伸びが $\mathrm{Cn}$ 以上に なるとボルト 1 と 2 の追加軸力の和が外力より大きく なる、これは，てこ作用により接合面に生ずる反力が 大きくなるためである.

\section{2 初期締付けカが各々異なる场合}

実際の場合, 各ボルトの初期締付力が均一とならな い場合があると考兄られる. 初期締付け力が各々異な る場合に括いても外力と各ボルトの軸力の関俰が求ぬ られると同様の方法で締付線図を表すことができる.

図10は初期締付け力がボルト 1,2 で異なる場合の 外力と軸力の関係を示す.この場合は着力点に近いボ ルト 1 の初期締付け力が材端側のボルト 2 の初期締付 け力よりも低くなっている. 図 8 と比較すると, ボル 卜 2 の初期締付け力が図 8 の場合より高いにもかかわ 


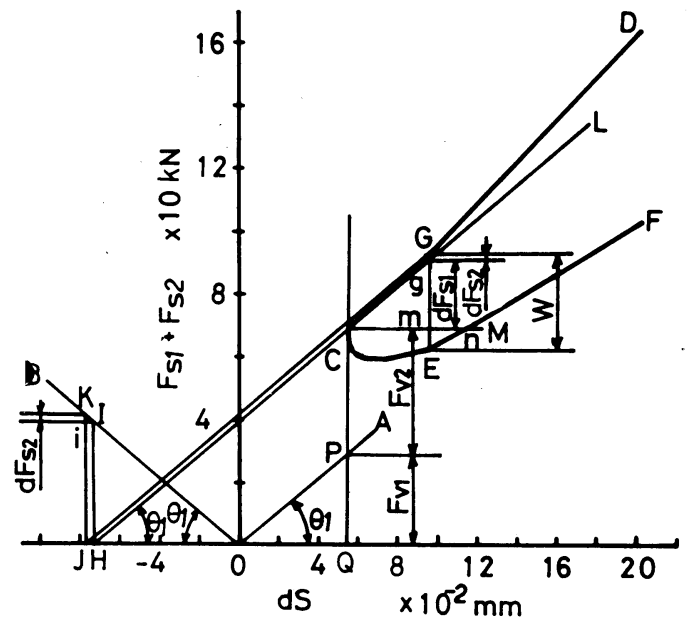

Fig. 11 Force-deformation diagram of multi-bolted joint

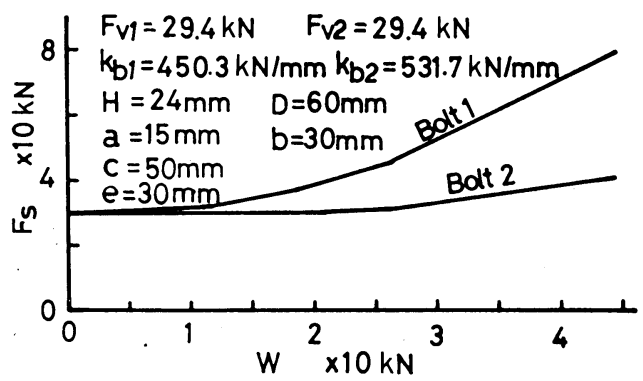

Fig. 12 The relationship between load and axial tension

らずボルト 1 の軸力増加はほとんど同じ位であること がわかる．この関係を図 9 と同様の方法で締付線図に 表したものが図 11 である. 図中の記号は図 9 と同じ であり，各ボルト軸力の和とボルト 1 の伸びの関係を 表す CGD および接合面における圧縮力と反力の和に 対するボルト 1 の伸びの関係を表す CEF が求められ ると, 図 9 と同様に任意の外力に対するボルト 1 およ び 2 の軸力および伸びが推定できる.

\section{3 ボルトのばね定数が各々異なる場合}

複数ボルト締結の場合には同一寸法のボルトを使用 するのが一般的であるが，締付作業や締結部の機能， 締結体の形状などによって，ボルトの寸法が各々異な る方が合理的な場合もある．そのような場合にはボル トのばね定数は各々異なった値を持つ. 図 12 は着力 点に近いボルト 1 のばね定数が材端側のボルト 2 より 低いばね定数の場合の外力と軸力の関係を示す。ここ で, ボルト 2 は $\mathrm{M} 12$, 軸部長さ $18 \mathrm{~mm}$ の植込みボル トで, ボルト 1 はボルト 2 の軸部直径を $10 \mathrm{~mm}$ とし て計算している. この図は図 8 とほとんど同様の傾向

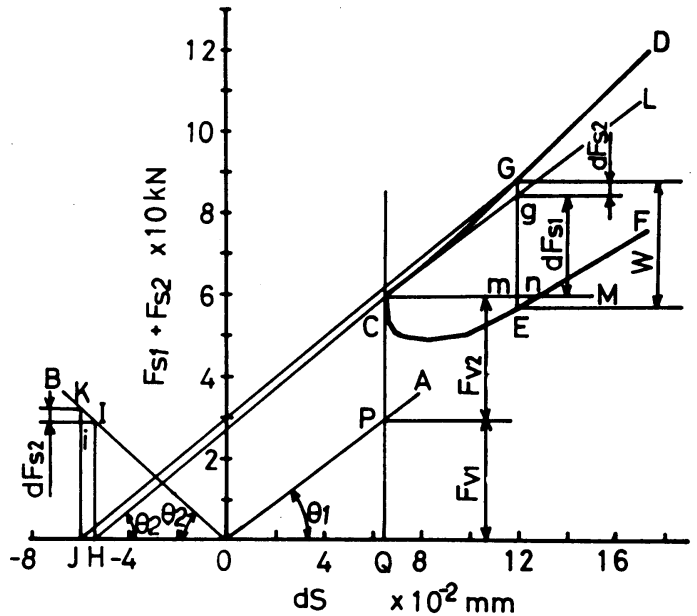

Fig. 13 Force-deformation diagram of multi-bolted joint

を示している、ボルトのばね定数が各々異なっている 場合にもばね定数が各々等しい場合と同様の方法で締 付線図を表すことができる.図 13 は図 9 と同様の方 法で図 12 の関係を締付線図で表したものである。こ の場合も図 9 と同様の方法で各々のボルトの状態を推 定することができる，図中の記号は図 9 と同じである が，ボルト軸力と伸びの関係を表す $\mathrm{OA}, \mathrm{OB}$ はばね定 数が各々異なるので $\mathrm{OA}$ 打よび $\mathrm{OB}$ と横軸とのなす 角 $\theta_{1}, \theta_{2}$ は次式で与兄られる.

$$
\left.\begin{array}{l}
\theta_{1}=\tan ^{-1} k_{\mathrm{b} 1} \\
\theta_{2}=\tan ^{-1} k_{\mathrm{b} 2}
\end{array}\right\}
$$

また， $\mathrm{CH}$ と横軸とのなす角を $\theta_{2}$ とすることによ り, 初期締付状態に打けるボルト 2 の軸力および伸び が各々 $\mathrm{IH}, \mathrm{OH}$ として求められる. 任意の点 $\mathrm{G}$ に打け る各ボルトの状態は $\mathrm{GJ}$ を $\mathrm{CH}$ に平行に引くことによ り図 9 と同様の方法で求めることができる.

以上の方法により複数ボルトの場合には各ボルト軸 力の和を表す CGD を適当に仮定できるならばボルト 1 の状態からボルト 2 の状態を推定できる。 また，接 合面に発生する反力が求められると残留締付け力も推 定できる。

\section{5. 結 論}

本研究で得られた主な結論は以下のと扔りである.

（1）ボルト軸力の増加や接合面の圧縮力, 反力が簡 単に計算できるばね-はりモデルによる解析法を 用いて，従来から例の少ない偏心外力を受けるね じ締結体の締付線図を作図するとともに，従来か ら例のない複数ボルトの締付線図として, 直列に 並ぶ 2 本ボルト締結体を例に, 各ボルト軸力の和 
とボルトの伸びの関係として締付線図を表す方法 を提案した.

（2）てこ作用により接合面に生ずる反力とボルト の伸びの関係を締付線図の中に作図することによ り，締付線図から，ある外力に対する各ボルトの 追加軸力，追加伸びが推定でき，残留締付け力も 推定できる.

最後に，本研究を進めるに当たり御助言を頂いた室 蘭工業大学星野悟教授に深く感謝いたします。

\section{参 考文 献}

1）田中 稔：ばね・はりモデルによるねじ締結体の応力解析 ——単一ボルト締結体の場合, 精密機械, 51，12（1985） 2265 .

2）田中 稔，北郷 薫：ばねーはりモデルによるねじ締結体 の応力解析一一偏心外力を受ける場合, 精密工学会誌, 52, 4 (1986) 655.

3）田中 稔，北郷 董：ばねーはりモデルによるねじ締結体 の応力解析一一複数ボルトによる締結体の場合, 精密工学 会誌, 53, 4 (1987) 664 .

4）吉本 勇, 丸山一男, 沢 俊行, 西口信幸：ねじ締結体の 内力係数, 日本機械学会論文集，42，359（1976） 2174 .

5）山本 晃：対じ締結体の理論と計算，養賢堂（1975）58。

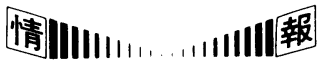

(p. 1727 より続く)

3. 動剛性についてどの部門で研究しているか

メーカの場合，最も多いのが研究・開発部門 (56.0\%) である．次いで設計部等の現場 $(40.0 \%)$ である. しか し，気になることは，「外部に委託して」，「研究していな い」「ての他」の回答が合わせて $14.7 \%$ ああることであ る. 約 15\% が自社内で動剛性について研究していない ことになる。 これは, 問 7 の試験装置の設備状況と対応 している、これがユーザになると，「外部に委託して」, 「研究していない」，「その他」の回答が合わせて $29.4 \%$ にもなる。

\section{4. 動剛性と工作機械の性能との間に関係はあるか}

動剛性と工作機械の性能の関係について, $76.0 \%$ が大 いに関係するとしている.これは，いままでの動剛性に ついて問題になったことがあるか否かの質問とも関連し た質問であるが，ユーザ，メーカ共にその重要性を認め ている,

\section{5. 動岡性の改善例}

メーカで最も多い改善例は,

リブやステーを多くした $(57.3 \%)$

静剛性を高くした（52.0\%）

である.これはリブやステーを多くして静剛性を上げて, 動剛性を改善したと理解して良いであろう。

高減衰材を使って動剛性を改善した例も $26.7 \%$ に上 るが，その内，具体的な対策として

（1）ベッドやベースをコンクリート充てん構造に

（2）従来鋼板溶接構造を高減哀鋳物構造に

(3) その他

の 3 つの方法がとられている.

構造上, 主軸や案内面は工作機械の創成運動, 切削能 力を支配する重要な要素であるが，動剛性向上対策とし ては，主軸軸受の予圧を高くする方法（38.7\%）が比較 的多くとられている. この予圧を高くするのも，結果的 には主軸系の静剛性を高くすることと同じである.
ここで興味ある結果は, 案内面の構造を変更したと回 答した中で，転がり案内面から滑り案内面に変えて動剛 性を改善した例が多いことである，滑り案内面の場合で も摩擦力を低減する目的でふっ素樹脂貼付案内面に変え ているものが多い.

6. 動剛性を改善するのに最も効果の大きいものは何 か

最も回答の多かったものを順番に 5 項目上げると, 表 5.2 のようになっている. これがューザになると順位が 入れ替わり，ユーザの手で修正が施せそうなジグ・取付 具が上位になっている.

\section{2 動剛性改善対策を施した箇所}

\begin{tabular}{|c|c|c|c|}
\hline- & \# & $=$ & + \\
\hline (1) 主軸 & $(57.3 \%)$ & (1) ベッド・コラム & $(58.8 \%)$ \\
\hline (2) ベッド・コラム & $(53.3 \%)$ & （2）軸受 & $(47.1 \%)$ \\
\hline （3）軸受 & $(45.3 \%)$ & (3) ジグ・取付具 & $(35.3 \%)$ \\
\hline (4) 案内面 & $(44.0 \%)$ & （4）主軸 & $(35.3 \%)$ \\
\hline (5) ジグ・取付具 & $(32.0 \%)$ & （5）送り駆動機構 & $(29.4 \%)$ \\
\hline
\end{tabular}

\section{7. 動岡性試験装置の設備状況}

メーカでは既に設備している，設備する予定であるの いずれかであるものが $69.4 \%$ にも上る. ユーザは逆に 設備する予定はないが $64.7 \%$ もあり, 対照的である. そ の設備の大半は衝撃加振法に対応でき, 手軽に試験の行 える圧電式インパクトハンマ $(84.9 \%)$, 圧電式加速度計 (96.2\%), FFT アナライザタイプの伝達関数解析装置 (92.5\%) である. そして，解析結果の表示は，コンプラ イアンス伝達関数 $(69.8 \%)$, イナータンス伝達関数 (39.6\%) で表示しており, 開発レベルでは, 多点の伝達 関数を測定し，実験的モード解析まで $34.0 \%$ もが行っ ている. 